\title{
EVALUASI PRODUKSI DAN KUALITAS SEMEN SAPI SIMMENTAL TERHADAP TINGKAT BOBOT BADAN BERBEDA
}

\author{
F. KHAIRI \\ Program Studi Peternakan \\ Fakultas Pertanian Universitas Syiah Kuala \\ Email:khairi.fitrah@gmail.com
}

\begin{abstract}
This study was conducted to find the rate of body weight ideal study Simental cows to produce production and the best quality fresh semen. The material used in this study were 9 males Simental cows were divided into 3 ranges of body weight as a treatment that is $P 1=$ low body weight $(822-878 \mathrm{~kg}), P 2=$ moderate weight $(910-958 \mathrm{~kg})$ and $P 3=$ body weight high (983-1041 kg). The number of cows in each group of body weight is considered as replicates. The method used was a survey method. The research is designed to completely randomized design (CRD) with 3 treatments and weight range 3 replications. Each stud cows housed cement 2 times per week for 12 weeks so that each cow cement accommodated as many as 24 times. Parameters observed in this study is that the volume of fresh cement production of cement per shelter and semen quality bulls include sperm motility and concentration of spermatozoa. Data were analyzed using analysis of variance, followed by Duncan test if there are significant levels of different body weights. The results showed that differences in body weight bulls simental not significant $(P>0.05)$ for fresh semen volume, sperm motility and concentration of spermatozoa. Mean semen volume is best found in the high body weight group, whereas sperm motility and concentration of spermatozoa present in body weight groups were.
\end{abstract}

Keywords : body weight, semen volume, motility, concentration

\section{PENDAHULUAN}

Kualitas semen sapi pejantan mempunyai peranan yang sangat penting dalam pelaksanaan perkawinan, baik secara alami maupun Inseminasi Buatan (IB). Inseminasi buatan merupakan teknik perkawinan dengan memasukkan semen segar atau semen beku ke dalam saluran kelamin sapi betina menggunakan alat yang dibuat oleh manusia. Hal ini bertujuan untuk memperbaiki mutu genetik ternak, menghindari penyebaran penyakit kelamin dan meningkatkan jumlah keturunan dari pejantan unggul (Hafez, 2000).

Sapi simental merupakan ternak sapi yang memiliki keunggulan dengan tingkat pertumbuhan dan harga jual yang tinggi. Produksi dan kualitas semen yang dihasilkan dari pejantan unggul mempunyai peranan yang penting dalam Inseminasi Buatan, karena faktor yang mempengaruhi keberhasilan IB sangat dipengaruhi oleh kualitas semen yang digunakan dari pejantan yang memiliki produksi dan kualitas semen yang baik.

Pejantan unggul yang baik mempunyai produksi dan kualitas semen yang bagus dengan bobot badan yang tinggi. Salah satu faktor yang mempengaruhi produksi dan kualitas semen adalah bobot badan. Menurut Susilawati, et al (1993) produksi dan kualitas semen yang dihasilkan dari seekor pejantan dapat dipengaruhi oleh beberapa faktor, yaitu bobot badan, umur, sifat genetik, frekuensi ejakulasi, pakan, suhu dan musim. Sato (1992) menyatakan bobot badan sapi jantan berhubungan erat dengan ukuran testis, pejantan dengan volume testis dan lingkaran skrotum lebih besar menghasilkan spermatozoa yang juga lebih banyak.

Berdasarkan uraian tersebut, maka perlu dilakukan penelitian tentang pengaruh tingkat bobot badan yang berbeda terhadap produksi dan kualitas semen sapi Simental. Penelitian ini bertujuan untuk menemukan bobot badan ideal guna menghasilkan 
produksi dan kualitas semen sapi Simental yang terbaik di BIB Ungaran.

\section{MATERI DAN METODE}

Penelitian telah dilaksanakan pada Balai Inseminasi Buatan Ungaran. Materi yang digunakan dalam penelitian ini adalah 9 ekor sapi pejantan Simental yang dibagi menjadi 3 kisaran bobot badan sebagai perlakuan yaitu : $\mathrm{P} 1$ = bobot badan rendah $(822-878 \mathrm{~kg}), \mathrm{P} 2=$ bobot badan sedang $(910-958 \mathrm{~kg}), \quad$ P3 $=$ bobot badan tinggi (983-1041 kg).

Jumlah sapi pada masing-masing kelompok bobot badan sejumlah 3 ekor dianggap sebagai ulangan. Metode yang digunakan adalah metode survei. Penelitian dirancang dengan Rancangan Acak Lengkap (RAL) dengan 3 perlakuan kisaran bobot badan dan 3 ulangan. Masingmasing sapi pejantan ditampung semennya
2 kali per minggu selama 12 minggu sehingga masing-masing sapi ditampung sebanyak 24 kali. Penampungan semen segar sapi Simental di BIB Ungaran dilakukan setiap hari Senin dan Kamis pada pukul 07.00. Parameter yang diamati pada penelitian ini adalah produksi semen segar yaitu volume semen per penampungan dan kualitas semen sapi pejantan meliputi motilitas spermatozoa dan konsentrasi spermatozoa. Data dianalisis menggunakan analisis ragam, dilanjutkan uji Duncan jika terdapat pengaruh perlakuan. Data diolah menggunakan bantuan sofware SPSS versi 16.

\section{HASIL DAN PEMBAHASAN}

\section{Volume Semen}

Volume semen segar sapi Simental pada ketiga kelompok bobot badan sapi Simental dapat dilihat pada Tabel 1.

Tabel 1. Volume semen segar sapi Simental

\begin{tabular}{|c|c|}
\hline Bobot badan & Volume rata-rata \\
\hline 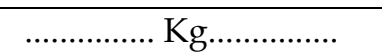 & ……........... $\mathrm{ml}$................. \\
\hline Rendah (822 dan 878 ) & 6,17 \\
\hline Sedang (910 dan 958) & 6,11 \\
\hline Tinggi (983 dan 1041 ) & 6,36 \\
\hline
\end{tabular}

Hasil analisis ragam menunjukkan tingkat bobot badan yang berbeda dari pejantan sapi simental tidak berpengaruh terhadap volume semen segar $(\mathrm{P}>0,05)$. Rata-rata volume semen segar yang dihasilkan oleh setiap tingkat bobot badan rendah, sedang, dan tinggi secara berturutturut adalah $6,17 \mathrm{ml}, 6,11 \mathrm{ml}$, dan $6,36 \mathrm{ml}$. Feradis (2010) menyatakan volume semen sapi berkisar 5-8 $\mathrm{ml}$. Volume semen segar Sapi Simmental yang diperoleh selama penelitian termasuk normal sesuai pendapat Luthan (2010) yang menyatakan hasil yang layak pada semen sapi adalah berwarna putih susu sampai krem dan untuk volumenya berkisar 5-10 ml.

Pemeriksaan volume merupakan salah satu syarat yang diperlukan untuk mengetahui kuantitas semen segar setelah penampungan. Menurut Kartasudjana
(2010) volume semen tergantung pada spesies ternak, sapi dan domba umumnya mempunyai volume ejakulat rendah, sedangkan semen babi dan kuda mempunyai volume ejakulat yang tinggi. Dari jenis ternak tersebut, volume semen juga dipengaruhi oleh bangsa, bobot badan, umur, pakan dan frekuensi penampungan.

Data penelitian ini menunjukkan sapi Simental pada kelompok bobot badan tinggi (983 dan $1041 \mathrm{~kg}$ ) memiliki volume lebih banyak dibanding kedua kelompok lainnya, meskipun secara statistik tidak berbeda nyata. Bobot badan sapi pejantan ber banding lurus dengan besarnya testis, ukuran testis yang besar mempunyai tubuli seminiferi yang lebih banyak sehingga akan meningkatkan jumlah spermatozoa yang didukung seminal plasma yang juga lebih banyak. Ukuran testis tersebut berkorelasi 
positif dengan pertambahan bobot badan (Mathevon, et al. 1998). Pendapat ini didukung oleh Sato (1992) yang menyebutkan bobot badan sapi jantan berhubungan erat dengan ukuran testis, pejantan dengan volume testis dan lingkaran skrotum lebih besar menghasilkan spermatozoa yang juga lebih banyak. Pendapat senada juga dikemukakan Feradis (2010) bahwa perbedaan volume semen segar bisa disebabkan ukuran testis antar bangsa yang berbeda.

\section{Motilitas Spermatozoa Semen Sapi Simental}

Hasil pemeriksaan motilitas spermatozoa pada ketiga kelompok bobot badan Sapi Simental dapat dilihat pada Tabel 2.

Tabel 2. Motilitas spermatozoa Sapi Simental

\begin{tabular}{|c|c|}
\hline Bobot badan & Motilitas rata-rata \\
\hline 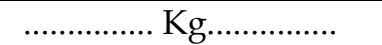 & 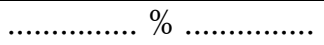 \\
\hline Rendah (822 dan 878 ) & 19,58 \\
\hline Sedang (910 dan 958) & 48,06 \\
\hline Tinggi (983 dan 1041 ) & 38,75 \\
\hline
\end{tabular}

Hasil analisis ragam menunjukkan tingkat bobot badan yang berbeda tidak berpengaruh nyata terhadap motilitas spermatozoa sapi Simental $(\mathrm{P}>0,05)$. Ratarata motilitas individu spermatozoa yang diperoleh dengan tingkat bobot badan rendah, sedang dan tinggi berturut-turut adalah $19,58 \% ; 48,06 \%$ dan $38,75 \%$. Ratarata motilitas spermatozoa pada Tabel 2 menunjukkan nilai yang lebih rendah jika dibandingkan hasil penelitian Arifiantini et al. (2005) yang menyatakan persentase motilitas individu semen sapi Simmental yaitu $71,36 \pm 16,446 \%$. Motilitas spermatozoa untuk sapi dengan bobot badan sedang masih dalam kisaran normal yaitu 48,08\%. Hal ini sesuai pendapat Toelihere (1993) besaran persentase motilitas individu sapi yang normal (fertile) mempunyai motilitas individu $40-75 \%$ spermatozoa yang aktif progresif. Motilitas spermatozoa di bawah $40 \%$ menunjukkan nilai semen yang kurang baik dan berhubungan dengan infertilitas. Rendahnya motilitas spermatozoa pada penelitian disebabkan oleh pengaruh musim yang erat kaitannya dengan suhu dan curah hujan. Pelaksanaan penelitian pada bulan Oktober-Desember jatuh pada musim hujan dimana kondisi lingkungan berada pada suhu rendah dan curah hujan tinggi. Hal ini yang menyebabkan menurunnya motilitas spermatozoa. Hal ini sesuai pendapat Hafez (2000) yang menyatakan perubahan musim dan lamanya penyinaran dapat menghambat produksi FSH yang dapat menghambat proses spermatogenesis oleh testis.

Persentase motilitas individu pada kelompok sapi dengan bobot badan sedang (910 dan $958 \mathrm{~kg}$ ) mempunyai nilai motilitas tertinggi dibanding kelompok sapi lainya yaitu $48,06 \%$. Perbedaan motilitas individu spermatozoa semen segar sangat terkait dengan keberadaan seminal plasma yang berfungsi sebagai sumber energi. Energi yang digunakan untuk motilitas spermatozoa berasal dari perombakan Adenosin Tri Pospat (ATP) di dalam selubung mitochondria melalui reaksireaksi penguraiannya menjadi Adenosin Di Pospat (ADP) dan Adenosin Mono Pospat (AMP). Energi yang dihasilkan tersebut akan digunakan sebagai pergerakan (energi mekanik) atau sebagai biosintesis (energi kimiawi). Dalam semen terdapat empat bahan organik yang dapat dipakai secara langsung maupun tidak langsung oleh spermatozoa sebagai sumber energi untuk kelangsungan hidup dan motilitas spermatozoa, bahan-bahan tersebut berupa fruktosa, sorbitol, glyceryl phosporil choline (GPC) dan plasmalogen (Toelihere, 1993).

\section{Konsentrasi Spermatozoa Semen Sapi} Simental 
Hasil pemeriksaan konsentrasi spermatozoa pada ketiga kelompok bobot Tabel 3. Konsentrasi spermatozoa Sapi Simental

\begin{tabular}{|c|c|}
\hline Bobot badan & Motilitas rata-rata \\
\hline 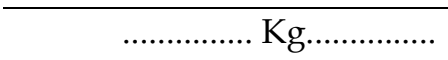 & 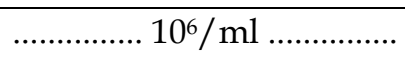 \\
\hline Rendah (822 dan 878 ) & 1371,55 \\
\hline Sedang (910 dan 958 ) & 1484,68 \\
\hline Tinggi (983 dan 1041) & 1278,63 \\
\hline
\end{tabular}

badan Sapi Simental dapat dilihat pada Tabel 3.
Pemeriksaan konsentrasi merupakan salah satu syarat yang diperlukan untuk mengetahui kuantitas semen segar setelah penampungan. Hasil analisis ragam menunjukkan tingkat bobot badan yang berbeda tidak berpengaruh terhadap konsentrasi spermatozoa semen segar $(\mathrm{P}>0,05)$. Meskipun secara statistik tidak berbeda nyata, namun sapi Simmental pada kelompok bobot badan tinggi menunjukkan konsentrasi semen yang paling rendah dibandingkan kelompok bobot badan yang lain dengan rata-rata $1278,63 \quad(106 / \mathrm{ml})$. Hasil ini sesuai pendapat Komar et al. (2012) bahwa hubungan antara bobot badan dengan motilitas dan konsentrasi semen mempunyai hubungan negatif sehingga semakin tinggi bobot badan, maka semakin rendah motilitas dan konsentrasi semennya. Semakin tingginya bobot badan pejantan tidak diikuti dengan peningkatan jumlah konsentrasi spermatozoa dalam semen segar. Menurut Toelihere (1981) sapi cenderung mempunyai volume yang rendah dengan konsentrasi yang tinggi.

Salisbury dan Van Demark (1985) menyatakan konsentrasi spermatozoa akan mengikuti perkembangan seksual dan kedewasaan, kualitas pakan yang diberikan, kesehatan alat reproduksi, besar testis, umur dan frekuensi ejakulasi pejantan. Konsentrasi spermatozoa semen segar sapi Simental yang diperoleh selama penelitian termasuk normal. Sesuai pendapat Soedjana (2007) bahwa pemeriksaan dan penghitungan konsentrasi menggunakan spectrophotometer dengan konsentrasi spermatozoa semen sapi Simental minimal adalah $1.000 \times 10^{6}$ spermatozoa per $\mathrm{ml}$. 
Komar, B. S., Lestari, D. T. Dan Prasakti, R. 2012. Hubungan Antara Bobot Badan dengan Performan Reproduksi Kambing Kosta. Fakultas Peternakan Universitas Padjadjaran. Bandung.

Luthan, F. 2010. Pedoman Teknis Alat Mesin dan Ulib Budidaya Ternak Ruminansia. Direktorat Budidaya Ternak Ruminansia. Jakarta. http://www.ditjennak.go.id/regulasiPednis AlsinUlib.pdf. Diakses tanggal 29 Oktober 2016.

Mathevon, M., Buhr, M., and Dekkers, J.C.M. 1998. Environmental, Management and Genetic Factors Affecting Semen Production in Holstein.

Salisbury, G. W. and Vandemark, N. L. 1985. Fisiologi Reproduksi dan Inseminasi Buatan Pada Sapi. Gajah Mada University Press. Yogyakarta (Diterjemahkan oleh R. Djanuar).
Sato, L, 1992. Anatomy of Reproductive System. In : S. Kudo (Ed.). Artificial Insemination Manual for Cattle.

Soejana, T. 2007. Petunjuk Teknis Produksi dan Distribusi Semen Beku. Peraturan Dirjen Peternakan.

http://www.ditjennak.go.id/regulasi\%5CPe rditjen12207_2007.pdf. Diakses pada tanggal 29 Oktober 2016.

Susilawati, T., Suryadi, Nuryadi, Isnaini, N., dan Wahyuningsih, S. 1993. Kualitas Semen Sapi FH dan Sapi Bali pada berbagai Umur dan Berat Badan. Laporan Penelitian. Fakultas Peternakan Universitas Brawijaya. Malang.

Toelihere, R.M. 1981. Fisiologi Reproduksi Pada Ternak. Penerbit Angkasa. Bandung.

Toelihere, R.M. 1993. Inseminasi Buatan Pada Ternak. Penerbit Angkasa Bandung. 